\title{
Opportunities for walkability in Szeged and Valencia
}

Petra Szücs Cities traditionally concentrate a country's re-

First Hungarian Responsible sources and talents, and, thus, they have long been Innovation Association the hubs of innovation and economic growth. Re-

E-mail: cent rapid urbanization has brought numerous petra.szucs94@gmail.com challenges to our cities, including overcrowding, noise, and air pollution, to name a few. One area in which cities urgently need to innovate is urban

Miklós Lukovics

University of Szeged, Faculty of Economics and Business

Administration

E-mail: miki@eco.u-szeged.hu

Béla Kézy

Megakom Development

Consultants

E-mail: kezy@megakom.hu mobility. The use of motorised vehicles requires increasing amounts of space, which drastically reduces the amount and quality of living space for people. This results in various negative economic and social consequences. To improve the sustainability of urban mobility, cities develop environmentally friendly public transit systems and bicycle infrastructures. However, improving the simplest and most basic type of mobility-walking-has long been neglected. Fortunately, urban developers have increasingly realized during the past few years that making our cities more walkable is a critical part of the solution to the urban mobility challenge. This paper aims to answer the question: 'How is the concept of walkability interpreted in middle-sized European cities'. During our research, we conducted intercept surveys (participant observation, questionnaire, and experts' interviews) to investigate the extents of walkability

Keywords: and its improvement opportunities in Szeged and walkability, Valencia. We evaluated the findings using descripcity development, sustainable urban mobility, community economic development tive statistical methods. We conclude that the concept of 'walkability' could be useful as a city development tool in mid-sized cities. ${ }^{1}$

\footnotetext{
1 This study was conducted in the framework of CityWalk 'Towards energy responsible places: establishing walkable cities in the Danube Region', DTP1-1-045-3.1 project. The project was co-financed by the European Union and the Republic of Hungary in the framework of the Danube Transnational Programme.
}

Regional Statistics, Vol. 7. No.1. 2017: 152-178; DOI: 10.15196/RS07109 


\section{Introduction}

Since cities first existed, the basic mode of transportation in them has been walking. Therefore, cities have primarily been walkable settlements, in which the most important activities were accessible on foot. This arrangement worked well until the automobile was invented. The proliferation of automobiles in cities initially offered unprecedented opportunities for urban development, but, at this point, the automobile's benefits have long and increasingly been surpassed by its disadvantages, and disadvantages to urbanization have occurred.

Dysfunctional urban transit systems have had serious negative consequences, and it is not surprising that cities have made sizable investments in overcoming the problems. Although it requires a careful and complex solution, one aspect of sustainable urban transportation that is often forgotten is one that is simple, natural, and, even, relatively inexpensive. That aspect is 'walkability', which is an innovative and simple solution to cities' transportation problems. However, it is important to clarify that walkability is just one, albeit crucial, part of the solution, which includes development of public transit, bicycle infrastructure, and the application of advanced technologies, such as electric and autonomous systems and vehicles. Walkability is a common concept in the US and big cities in Western Europe; however, information on adapting mid-sized cities in Eastern Europe for walkability is less available.

Therefore, this study addresses the concept of walkability in Szeged ${ }^{2}$ by contrasting it with a selected European city, Valencia. ${ }^{3}$ Despite rapid motorisation, Valencia, similar to many Mediterranean cities, has maintained a high level of walkability. This paper first presents a review of the international literature on walkability to provide a broad context. Second, the topic is investigated from a practical perspective using quantitative methods. Then, the paper describes the empirical participant observation research conducted in both cities during five months, the interviews, and the questionnaire data on the walkability situations in Szeged and Valencia with a discussion on possible changes for the near future. Fourth, the paper provides suggestions for improving walkability in the studied cities based on the empirical results. Last, we summarize the study and present our conclusions about the results. The paper highlights that, within the framework of the study, we aimed to conduct pilot studies in two mid-sized European cities. Using our findings, we hope to obtain underlying information about the adaptability of the concept 'walkability' in mid-sized cities to serve as a foundation for further research.

\footnotetext{
${ }^{2}$ Szeged is the third largest city in Hungary in population, numbering 162,600. It has a well circumscribed city centre and its transportation is a mixture of walking, cycling, public transit, and personal vehicular transit.

${ }^{3}$ Valencia is the third largest city in Spain in population, numbering 790,201. It has a well circumscribed city centre and its transportation is a mixture of walking, cycling, public transit, and personal vehicular transit.
}

Regional Statistics, Vol. 7. No.1. 2017: 152-178; DOI: 10.15196/RS07109 


\section{The theory of walkability and its challenges}

People and their environments have dramatically changed over time. One major change is rapid, and seemingly unending, urbanization. People tend to leave rural areas and move to cities for the advantages of urban lifestyles, such as increased opportunities (Torrey 2004), cost savings (Lengyel-Rechnitzer 2004), access to more information (Lengyel 2010), and because cities are the engines of development, focal points for innovation (Cohen 2006), and areas of clustering (Vas et al. 2015). However, urbanization could have negative as well as positive effects on the natural environment (Sadorsky 2014), which is important to this study's perspective. The disadvantages include inadequate water and sanitation, lack of trash disposal, and industrial pollution (Torrey 2004). Cohen (2006) pointed out that traffic congestion in large cities is an extreme problem, and air pollution is a serious environmental concern. Green areas in cities are shrinking (Rechnitzer 2007) while transportation is increasing (Rechnitzer 2004, ITDP 2011). Therefore, the quality of the urban environment has gradually declined. Moreover, the comfortable access to destinations offered by urbanization displaces physical activity from daily life because moving around is limited to driving automobiles (Pavlik 2015).

Urban transit systems are major sources of negative environmental and other problems, and it is imperative that urban transit is more sustainable. The use of electric transportation combined with low-carbon electricity sources is clearly an important part of the solution (Hawkins et al. 2012) because they are environmentally friendly technologies (Wang-Santini 1993). However, this requires enormous resources and fails to address all of the important challenges of urban transportation. Many cities respond to traffic congestion problems with governmental investments in large-scale public transit systems (Cohen 2006), which is one obvious answer to the situation. However, this approach is expensive and still does not address all of the negative consequences, similar to electrification. Better walkability is a simple, cost-effective alternative way to address the problem that cannot be ignored. Dramatic increases in the use of active transportation (walking and cycling) for urban transportation is necessary. Although improved walkability and more walking could not replace the benefits of using electric automobiles or improving public transit, it probably is the most important part of the solution, particularly in small or poor cities. Rechnitzer (2007) claimed that the inner transportation connections of cities must be developed.

To gain a clear picture of the concept of 'walkability', this paper next presents the subject and highlights the advantages and possible effects of walkable communities based on previous studies conducted around the world. To deal with the issues of walkability, one must understand the meaning of 'walkability', and, based on various definitions, we can characterize neighbourhoods using the term 'walkability'. It means the extent to which it is easy, convenient, safe, and desirable to walk (Speck 2013) to where every important and daily-used establishment is accessible, namely, it does not take a lot of time to reach them.

Regional Statistics, Vol. 7. No.1. 2017: 152-178; DOI: 10.15196/RS07109 
Some possible benefits of walking

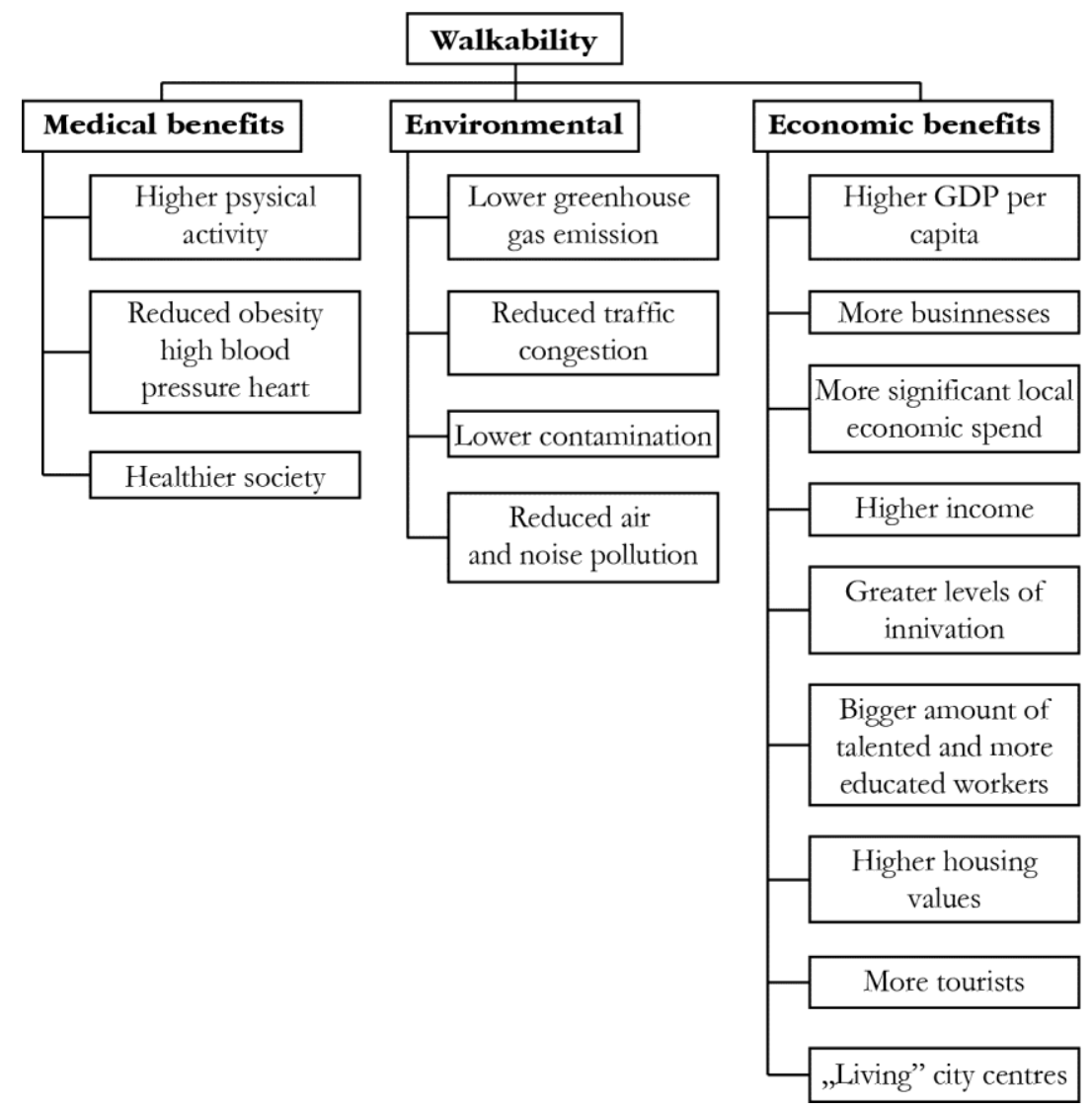

Sources: The author constructed the flow chart based on Giles-Corti et al. (2010), Benfield (2016), Florida (2010), Florida (2011), Leinberger-Lynch (2014), Eidmann et al. (2011), MARC (1998), Benfield (2014), SGA (2015), Florida (2014), Leinberger-Alfonzo (2012), FHWA (2014), Sauter et al. (2016), Simmons et al. (2015), Litman (2017), Swartz (2012), Forsyth et al. (2010), Wedderburn (2013), Cooper-Danzinger (2016), Litman (2014), SKM-PWC (2011), ABW (2016), and WHO (2013).

This section explains the effects of walkability. In walkable neighbourhoods, individuals and communities can enjoy concrete health and environmental and economic benefits (Giles-Corti et al. 2010, FHWA 2014, Sauter et al. 2016). Figure 1 lists some of the many positive effects of walkable neighbourhoods, although the list is not exhaustive. Regarding economic benefits, there are reduced user costs, direct and indirect economic impacts, benefits related to health savings, and environmental benefits (Simmons et al. 2015). Among the positive impacts on the economy, walkable places have relatively more businesses (Benfield 2016), higher incomes (Florida 2010), more innovation (Florida 2011), higher GDP per capita

Regional Statistics, Vol. 7. No.1. 2017: 152-178; DOI: 10.15196/RS07109 
(Leinberger-Lynch 2014), more significant money spent, higher property values (Litman 2017, Swartz 2012), and so on. Reducing the number of automobiles could decrease greenhouse gas emissions (Forsyth et al. 2010, Wedderburn 2013), traffic congestion (Eidmann et al. 2011, Cooper-Danzinger 2016), contamination, and air and noise pollutions (MARC 1998, Litman 2014). Regarding the health benefits of walking, there are direct and indirect benefits (SKM-PWC 2011). The physical effects of walking are self-explanatory because increased physical activity reduces obesity, high blood pressure, heart disease, and diabetes, thus creating a healthier society (Benfield 2014, ABW 2016, WHO 2013). Creating walkable compact cities is a global priority (Giles-Corti et al. 2014) because neighbourhoods with those features promote active modes of transportation, such as walking and cycling (TRB 2005). To this end, a complete pedestrian network in the built environment is necessary because it would have a positive influence on walking (Frank et al. 2011, Vale et al. 2016).

\section{How walkability is quantified in communities}

This section presents walkability from a practical perspective to gather ideas and establish the framework of the empirical study. By investigating the practical aspects of walkability, we can discover some crucial methods that could be important when quantifying walkability. The measures are important for assessing the current state of walking conditions, the changes to them, and setting and realizing goals (SieffWeissman 2016). Indicators are essential to measure and compare the features of streets and neighbourhoods (Porta-Renne 2005). In addition, quantification of walkability could have an essential role in transportation planning activities (Kuzmyak et al. 2006). Walk Score, Walkability Audit, and Transportation Walkability Index include methodologically important aspects that served as crucial inputs to this study. These methods contributed to the preparation of the questionnaire and interviews used in the study.

1. Walk Score, which measures the walkability of any location, was developed by the Walk Score advisory board (Walk Score 2007). To obtain the points of a given address, hundreds of walking routes to nearby amenities were analysed, and the distances to amenities in each category were the basis of the points. Walk Score analyses population density and road metrics to identify pedestrian friendliness. Based on the given points, addresses are classified into categories from the lowest to the highest scores: Walker's Paradise (90-100), Very Walkable (70-89), Somewhat Walkable (50-69), Car-Dependent (25-49), CarDependent (0-24). Based on the measurement of the extent of walkability in cities, some rankings are available for the most walkable cities and neighbourhoods in the world.

Regional Statistics, Vol. 7. No.1. 2017: 152-178; DOI: 10.15196/RS07109 
2. Walkability Audit is a method presented with an example by Eidmann et al. (2011). The authors measured the walkability in North Adams, US, through a Walkability Audit. The method used to evaluate streets for their walkable characteristics is a Walkability Audit, which considers numerous criteria (Agrawal and Schlossberg 2007). After the assessment, every street section is given a quantitative score and a qualitative assessment, which are used to make recommendations for improving the walking quality. The quantitative part of the audit tool comprises several parts and the specific criteria are ranked in each part on a scale of $1=$ worst to $5=$ best. The factors considered for commercial streets are sidewalks, crosswalks, signage, aesthetics and amenities, and safety. In the course of assessing these factors, impediments to walking in specific areas and areas for improvement can be identified. The qualitative part of the audit tool includes the presence of bicycle amenities, public transit stops, types and numbers of people present in the area, amount of available parking, and the streets' overall connectivity, which describes the dangerous and unpleasant parts of the area under evaluation. The project group used Geographic Information System (GIS) to identify the areas to be assessed on an aerial map and then input their data.

3. Transport Walkability Index is another method to assess the walkability of neighbourhoods, which was demonstrated with an example by Giles-Corti et al. (2014). The authors proposed that the goal of the Transportation Walkability Index is to measure transportation walkability and that calculation of three main variables is required, which are residential density, street connectivity, and land-use mix, because these characteristics are associated with walkability (Ewing-Cervero 2010, Clifton et al. 2015). After the calculation and harmonization of these data, the researchers imported the data to a GIS platform. Walkability indices are increasingly popular (Manaugh-El-Geneidy 2011). Without doubt, the correlation with travel behaviours could differ across individuals and households (Manaugh-E-Geneidy 2011).

Considering everything about the quantifiability of walkability, it is clear that many aspects of the above-described methods could be applied to this study's analysis.

\section{Walkability surveys in Szeged and Valencia}

We quantified walkability in two middle-sized European cities, Szeged and Valencia. The methodology was mixed methods research in light of the study's purpose. The mixed methods included participant observation, citizens' survey, and experts' interviews with city stakeholders and policymakers (Figure 2). The interviews were personally conducted because one co-author resided in Szeged and another author resided in Valencia.

Regional Statistics, Vol. 7. No.1. 2017: 152-178; DOI: 10.15196/RS07109 
Structure of the methodological process

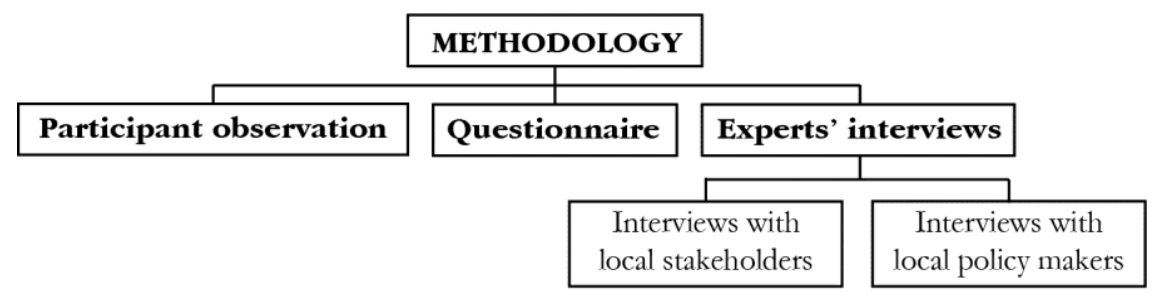

Source: Author.

There are unquestionable limitations to the survey we conducted. First, the two cities differ in size, extent of development, and transportation systems. In particular, Valencia has an underground system with several lines. All of these differences could influence the interpretability of the survey's results. However, this might not be a problem because Szeged and Valencia have well circumscribed city centres. This is important because the walkability of a city centre is decisive for every city. From the methodological perspective, the following points are essential to highlight regarding the mixed methods empirical research.

1. The first level of the primary research comprised personal observations conducted in both cities. These observations were important to gain insights into the walkability situations of the cities and to develop the questionnaire and the experts' interviews before surveying the citizens. During the personal observations, which were participant observation, field notes were taken to ensure records. Furthermore, we used several tools from the list developed by Gehl and Svarre (2013): counting, mapping, tracing, photographing, and test walks.

During the two-month fieldwork of daily observations in the Szeged city centre, which lasted 50 minutes each on average, 200 people on average passed by the observation spot, meaning that we recorded a total of about 12,000 observations. In Valencia, the foot traffic averaged 300 people per 50minute period, which totalled approximately 18,000 observations. Observations were performed at 15 different locations in both cities, such as busy intersections, important destinations (post office, medical centres, schools, and so on), and critical road intersections (where drivers and/or cyclists and pedestrians coincide or are close to each other). We followed 47 guided tourist group routes in Szeged and 53 of these routes in Valencia.

2. During questionnaire development, we created a list of questions adapted from some previous studies, the methods of Walk Score and the Walkability Audit, and our personal observations. It was important to put Szeged and Valencia into an international context based on existing scientific achievements. Because of the contributions of researchers, the questionnaire had two questions that were adopted from international research (a study by Southworth

Regional Statistics, Vol. 7. No.1. 2017: 152-178; DOI: 10.15196/RS07109 
conducted in Santa Rosa and a study on Toronto Public Health, 2012). The questionnaire was prepared for citizens in their first language. There were 18 closed-ended questions focusing on the most important factors of walkability. The benefits of a closed-ended questionnaire are its easy statistical analysis and possible quantification, if necessary; however, unfortunately, people cannot elaborate their thoughts. Altogether, 129 respondents completed the questionnaires in the two cities and the sample sizes in Szeged and Valencia were approximately equal. The samples were not representative.

3. The third level of the study comprised experts' interviews, in which we talked with five citizens in each city to gain deeper familiarity with the residents' ideas. These people were relatively more connected to particular aspects of walkability. For example, they were part of a civil organisation fighting to protect the environment, teachers/professors with influence on future citizens, dedicated to healthy lifestyles and frequent walking, or part of the community government with an influence on city planning. The structure of the experts' interviews differed depending on the interviewee. During the interviews, we asked open-ended questions similar to the questions in the online questionnaire to understand why people tend to think in a particular way about the walkability of their cities. The interviews with the two city policymakers (one from each city) included open-ended questions specific to the cities' current policies on walkability. These open-ended questions solved the limitations of the questionnaire's closed-ended questions because the interviewees could elaborate their answers.

\section{Results of participant observation}

We used the tools suggested by Gehl and Svarre (2013) in the following ways. We counted the people entering a certain shop and a gymnasium (as examples) to identify the most important establishments in people's daily lives. During the mapping, we drew symbols on a map to determine the frequency with which disabled people used certain streets. Tracing was a tool used to assess the numbers of pedestrians who avoided certain streets because of the lack of adequate lighting. We photographed to record the conditions of the walkways and crosswalks. Furthermore, we applied test walks in which we followed guided tourist groups to determine where they were going and the routes they used. The purpose of our participant observation was to prepare a basis for the questionnaire and experts' interviews.

Considering everything, the walkability of the two cities was different in some respects (e.g. there was significantly better infrastructure for disabled people in Valencia). However, there were similar features (e.g. both city centres were excellent place to walk). It is notable that both cities' centres were much better laid out than the layouts of the neighbourhoods. For example, all of the important institutions were concentrated in the city centres, whereas not all of them were present in the

Regional Statistics, Vol. 7. No.1. 2017: 152-178; DOI: 10.15196/RS07109 
neighbourhoods, which is understandable from the perspective of the city governments because they aim to make their cities appealing to visitors, who are relatively more likely to visit the centres. The outcomes of the participant observation were preliminary results and we aimed to minimize our subjectivity, although that is obviously impossible. We hoped to use these results to supplement the detailed questionnaires and interviews.

\section{Results of the survey}

The first section of the questionnaire asked for the respondents' opinions of their neighbourhoods from different standpoints. There were five response options (strongly disagree, disagree, neutral, agree, and strongly agree) provided for every statement. ${ }^{4}$ The opinions significantly differed between the two cities on some of the statements. First, the most outstanding was the number of trash cans on the streets in the neighbourhoods. Only 33\% of Szeged respondents agreed that the number of trash cans was sufficient, whereas $62 \%$ of the Valencia respondents agreed with the statement. Second, $88 \%$ of the Szeged respondents agreed and 11\% of them disagreed that they had good access to public transit stations (statement 6). In Valencia, $72 \%$ of the respondents agreed that they had good access, which is 16 percentage points below the $88 \%$ in Szeged, and 12\% disagreed to a certain extent. For statement 10, the difference between Szeged and Valencia was in the percentage of disagreements: $19 \%$ of the Szeged respondents and 31\% of the Valencia respondents disagreed with the statement. Another significant difference was found regarding disturbing objects on the walkways. In Szeged, 38\% of the respondents agreed to a certain extent that obstructions, fire hydrants, columns, or lampposts disturbed them while they were walking, but the same problems bothered $21 \%$ fewer of Valencia's respondents (17\% agreed).

The second section of the questionnaire was similar to the first section, except that the respondents were asked for their opinions on the same walkability features specifically about the city centre. ${ }^{5}$ A comparison of the two cities found that the responses were more positive for Szeged than for Valencia. For example, the Szeged responses to statements 1-7 had few disagreements and the maximum percentage was 3\%, which is insignificant. Regarding Valencia, disagreements with statements 1-7 also were low. In Szeged, 99\% of the respondents agreed with statement 1, meaning that almost every respondent agreed that the Szeged city centre was a good place to walk. Notably, 61\% of the Szeged respondents strongly agreed that the public lighting in the city centre was adequate. Generally, the Valencia respondents seemed to be satisfied with the previously mentioned aspects of walking, although their agreement was not as widespread as among the Szeged respondents. Com-

\footnotetext{
${ }^{4}$ See Appendix 1.

${ }^{5}$ Appendix 2 provides the text of the statements in the questionnaire.
}

Regional Statistics, Vol. 7. No.1. 2017: 152-178; DOI: 10.15196/RS07109 
pared to Szeged, 26\% fewer Valencia respondents agreed that the public lighting was adequate. Problematic issues in the city centre were similar to those in the neighbourhoods.

The third question concerned the ability to access important places on foot from the respondents' homes. Clearly, the list of establishments was not exhaustive. We asked the respondents about their access to schools, work, shops, banks, post offices, restaurants, hospital/medical centres, public transit stations, and churches. In Szeged, the majority of the respondents reported that, except for banks and hospi$\mathrm{tal} /$ medical centres, they could reach all of the important places on foot. The outstanding items were shops and public transit stations, for which $97.7 \%$ of the respondents reported access on foot. Regarding Valencia, the figures differ because we could not locate any places to which the majority of respondents could not walk. It seems that they were relatively more likely to easily reach any of the listed places on foot. In this city, three types of places had the highest accessibility: shops, hospi$\mathrm{tal} /$ medical centres, and public transit stations, all of which were at $97.6 \%$.

For questions 4 through 9, the respondents were asked to choose a value on a scale of 1-6. Question 4 asked for their opinions on how easily a person entering the city centre by automobile would be able to find a place to park. Parking close to the city centre was not considered perfect by the respondents in both cities. On the other hand, a strong difference was found between the cities in that, in Szeged, the highest frequency was 'rather good', at 36\%, and, in Valencia, the highest frequency was 'bad' (41\%) (Figure 3).

Figure 3

Parking opportunities near the city centres of Szeged and Valencia (\%)

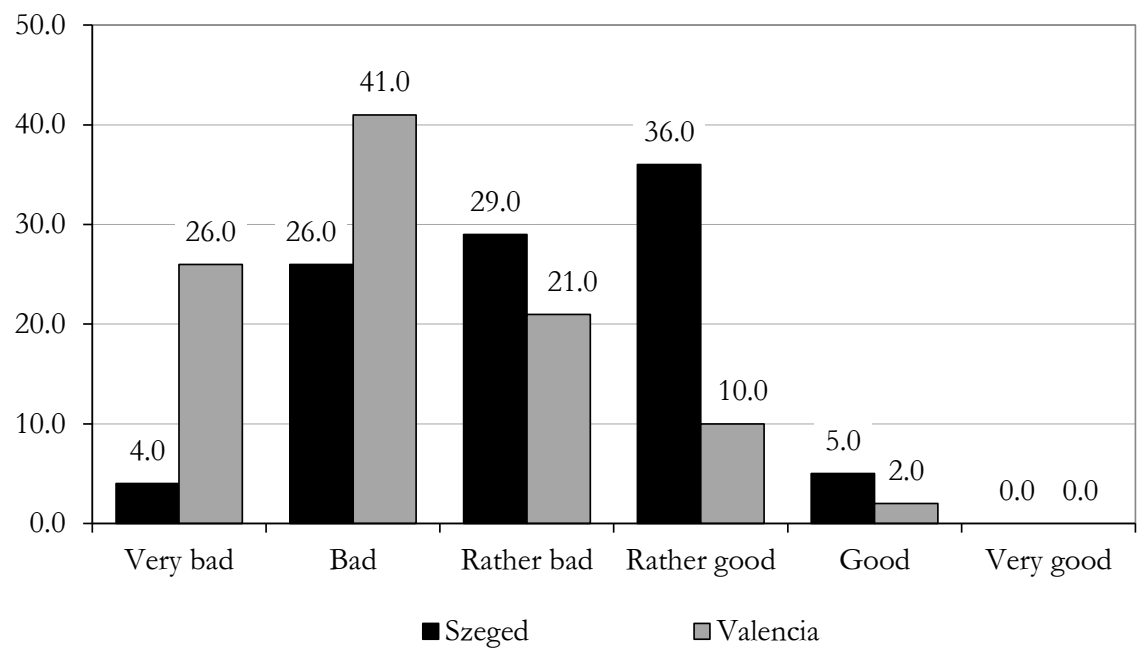

Source: Author.

Regional Statistics, Vol. 7. No.1. 2017: 152-178; DOI: 10.15196/RS07109 
This significant difference was not found in the responses to question 5, which is about the connections between the suburbs and the city centres. Although the Valencia respondents were most likely to rate their situation as 'rather good' (33\%), in Szeged, the respondents were most likely to rate their situation as 'good' $(47 \%)$. Therefore, it can be concluded that the suburbs are slightly better connected in Szeged than in Valencia (Figure 4).

Figure 4

The connections between the suburbs and city centres in Szeged and Valencia (\%)

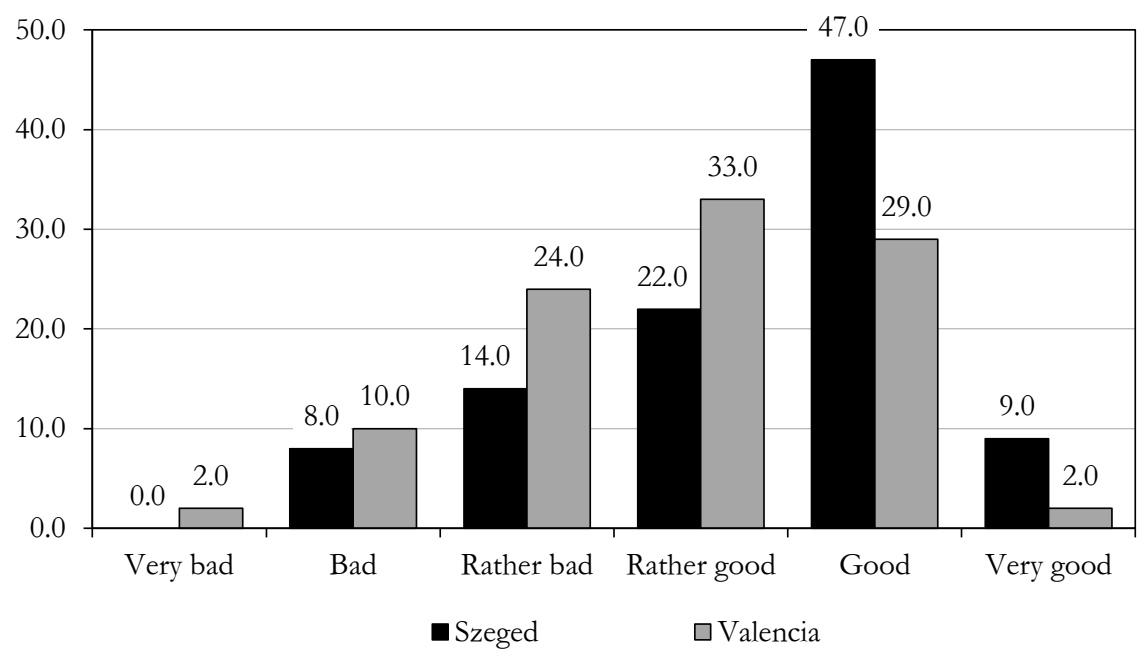

Source: Author.

Question 6 asked about the number of parked cars and the extent to which greenery disturbed visibility. The chart in Figure 5 shows that the Szeged and Valencia respondents assessed their situations differently. In Szeged, a slight majority $(53 \%)$ assessed the disturbance of visibility as rather serious (combined rather disturbing and disturbing), whereas, in Valencia, $67 \%$ of the respondents chose the opposite options (not disturbing at all, not disturbing, and rather not disturbing).

Question 7 asked the respondents to assess the respect given to pedestrians by road traffic. There was no significant difference between the two cities regarding vehicles' respect for pedestrians. According to the respondents in both cities, the most important tourist attractions were approachable on foot. Almost no one scored this as very bad or bad (Figure 6), and the combined good and very good responses were 68\% in Szeged and 64\% in Valencia, which are outstandingly high. This could be because tourist attractions are likely to be in city centres and these city centres were relatively more walkable.

Regional Statistics, Vol. 7. No.1. 2017: 152-178; DOI: 10.15196/RS07109 
Figure 5

The extent of disturbance of visibility by parked cars and greenery in Szeged and Valencia (\%)

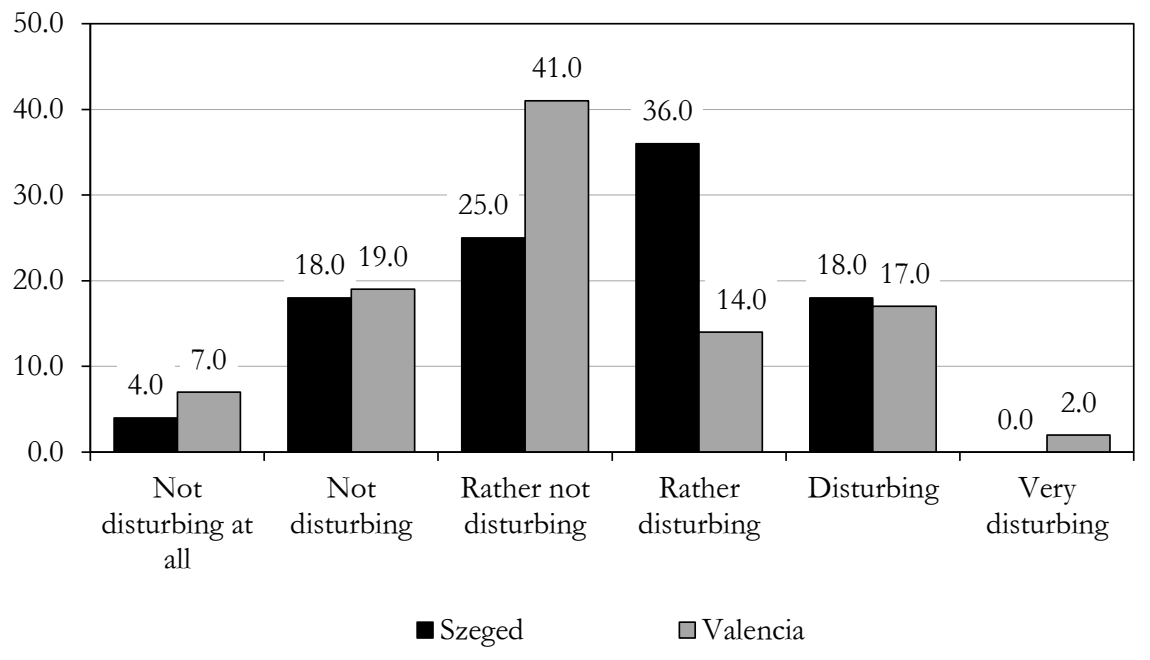

Source: Author

Figure 6

Pedestrian access to the most important tourist attractions in Szeged and Valencia (\%)

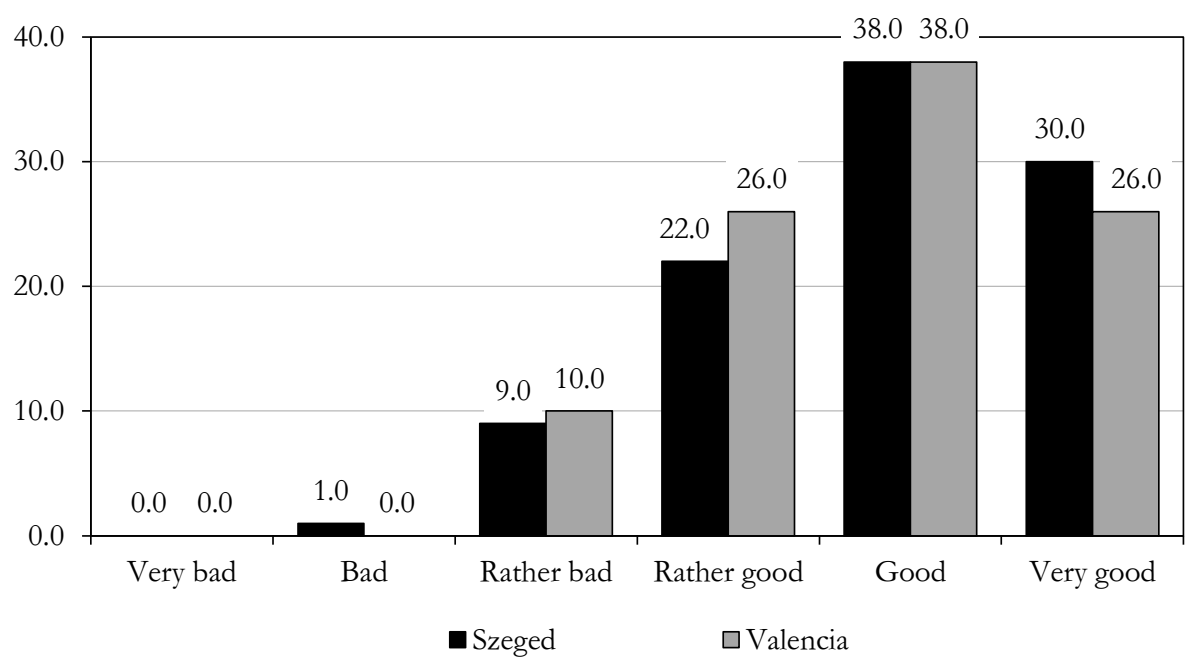

Source: Author.

The last question in this section concerned opinions of the usefulness of increasing the walkability in Szeged and Valencia. Overall, the respondents in both cities wanted walkability to be improved. Altogether, 91\% from Szeged and 76\% from

Regional Statistics, Vol. 7. No.1. 2017: 152-178; DOI: 10.15196/RS07109 
Valencia answered that it would be rather useful, useful, or very useful to do so. Figure 7 shows the extent to which people wanted some institutions in a walkable city centre. The respondents wanted parks and restaurants in Szeged and Valencia; they also wanted bakeries and dance clubs in Szeged (Figure 7).

Figure 7

Types of places desired for the walkable city centres in Szeged and Valencia (\%)

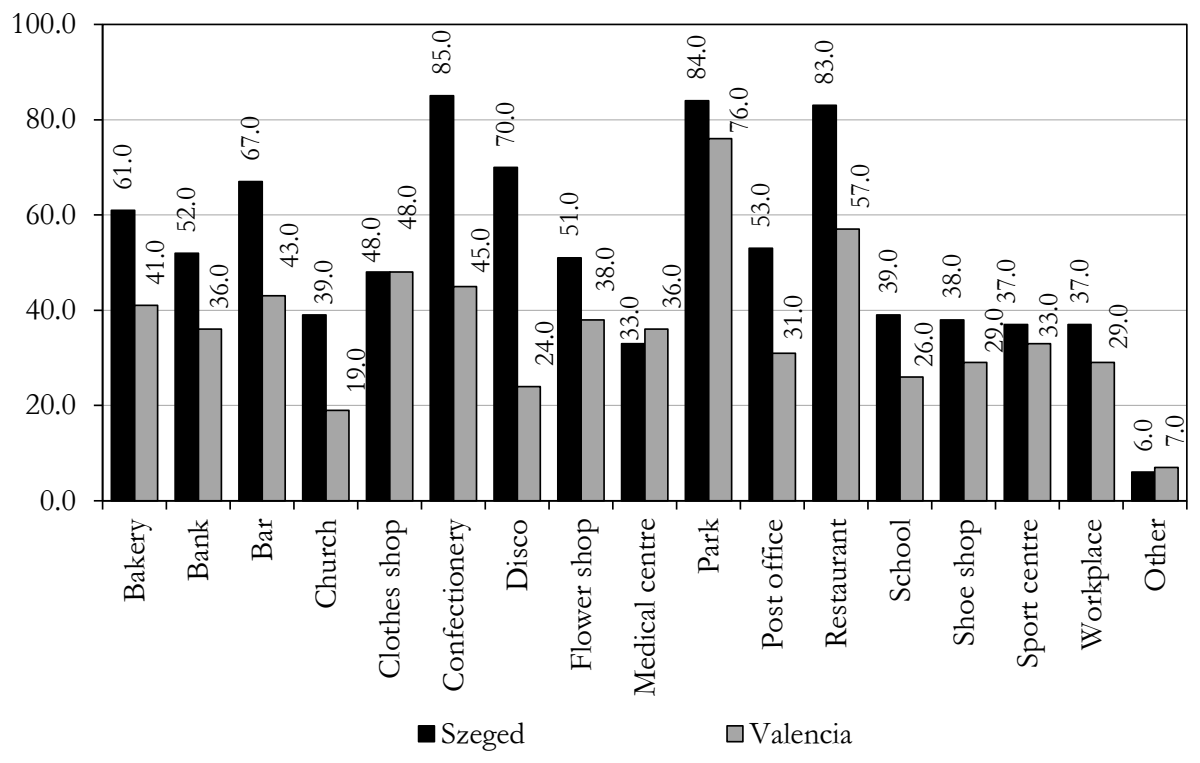

Source: Author.

The Szeged and Valencia respondents reported that they would be more willing to walk if the conditions were better, according to the high rate of yes answers $(70 \%$ in Szeged and 67\% in Valencia). Their opinions on the numbers of pedestrian zones differed in the two cities. In Szeged, no respondents reported that there were too many, although the majority (55\%) reported that the number was sufficient. In Valencia, $2 \%$ of the respondents reported that there were too many pedestrian zones, yet $53 \%$ of them considered the situation insufficient. Another difference between Szeged and Valencia concerned the average number of days on which the respondents walked for any reason. The Szeged respondents walked more than the Valencia respondents and there was more than three-fourths of a day difference between the two cities' averages: (5.09 days in Szeged versus 4.31 days in Valencia). Considering the amount of time taken for daily walks, the majority of the respondents in both cities (78\% in Szeged and 72\% in Valencia) walked zero-2 hours per day.

The last part of the questionnaire was about the respondents' characteristics with respect to gender, age, where they lived in the city, and whether their health was appropriate for walking. In Szeged, 65.5\% of the respondents were women, and, in

Regional Statistics, Vol. 7. No.1. 2017: 152-178; DOI: 10.15196/RS07109 
Valencia, 69\% were women. The respondents were in various age groups, but, in both cities, young adults aged 16-25 participated in the study more than people of other ages (49\% in Szeged and 53\% in Valencia). The respondents were from different parts of the cities. Regarding health, all of the respondents reported that his or her health was appropriate for walking.

To conclude, we argue that, overall, the levels of walkability in Szeged and Valencia could be improved and the citizens would appreciate those efforts. Based on the questionnaire data, the two cities had some problems in common regarding layout, but some problems were more evident in one or the other city. For example, in Szeged, everything was relatively more centralized and the major problems occurred in the neighbourhoods, whereas, in Valencia, that difference was not noticeable. Some aspects of development could focus on improving the lighting, the infrastructure for disabled people, increasing the number of trash cans, and establishing more parks, parking spaces, and other appealing features.

Figure 8

\section{Walkability Scores for Szeged, Valencia, and Santa Rosa}

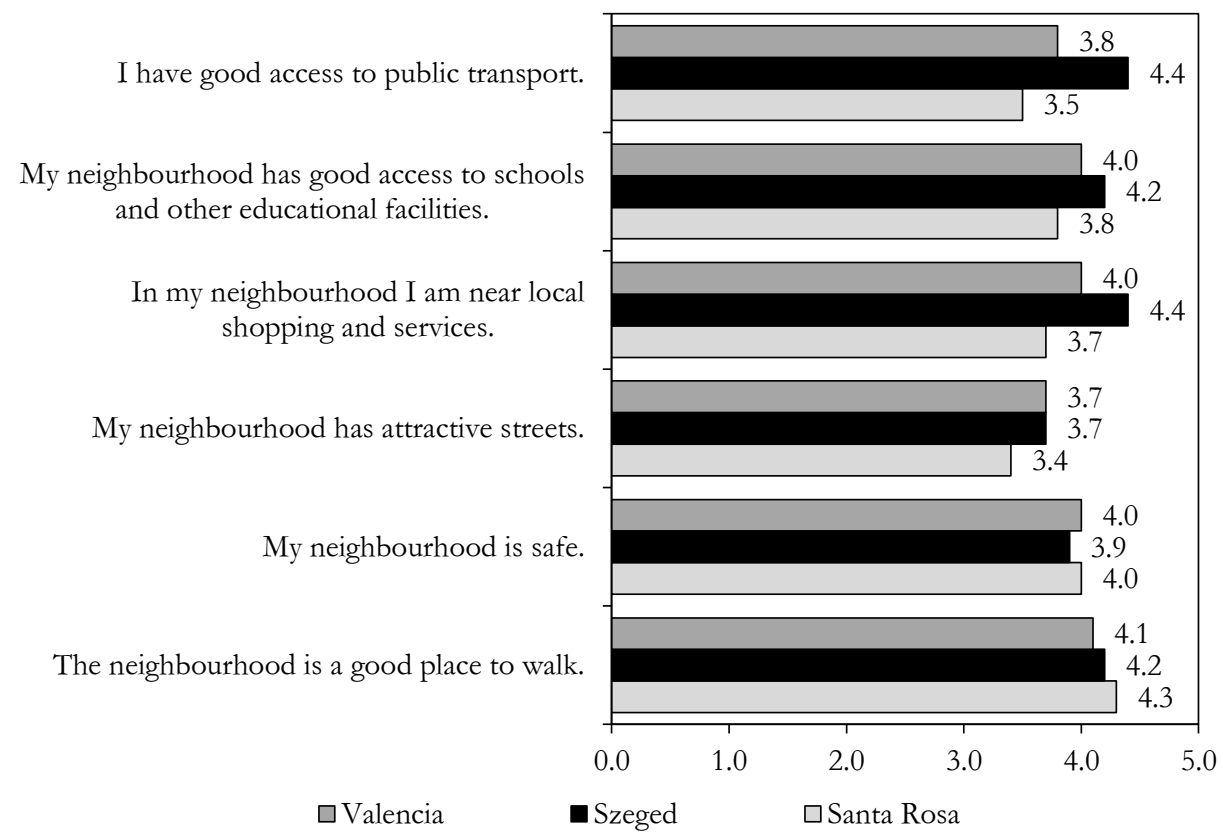

Source: Author.

To ensure an international dimension to the study, we compared the results on the first question of our questionnaire to an international survey conducted by

Regional Statistics, Vol. 7. No.1. 2017: 152-178; DOI: 10.15196/RS07109 
Southworth among 59 residents of Santa Rosa ${ }^{6}$. The respondents were asked to assess their neighbourhoods from different standpoints. Southworth evaluated the answers as quantified data, so we transformed our results to a scale where $1=$ strongly disagree, $2=$ disagree, $3=$ neutral, $4=$ agree, and $5=$ strongly agree. To compare the results, the means were calculated. We compared the answers on six statements (Figure 8). The data found that the ranking of the three cities on walkability was Szeged, then Valencia, and Santa Rosa was last.

We also put the average number of days that the respondents' walked for any reason into an international dimension by comparing Szeged and Valencia to the results of Frank et al. (2012), who studied 1,133 respondents in Toronto, Canada. The residents of Toronto walked a mean of 4.8 days for any reason, which was between Szeged (5.09 days) and Valencia (4.31 days) (Figure 9). The three cities were ranked from most to least average days walked for any reason as follows: Szeged, Toronto, and Valencia. Thus, we conclude that Szeged had better walkability than Santa Rosa and Toronto regarding the Walkability Scores and the average number of days walked for any reason, and Valencia was more walkable than Santa Rosa but less walkable than Toronto.

Figure 9

Mean number of days walked for any reason in Szeged, Valencia, and Toronto

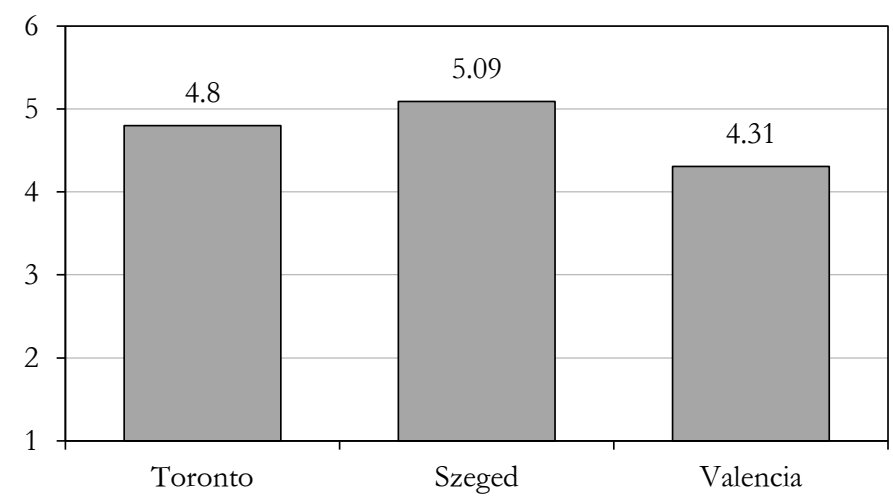

Source: Author.

\section{Results of the experts' interviews}

The third level of our primary research was experts' interviews, with which we aimed to solve the limitations of the questionnaire. This was an important effort because the questionnaire used closed-ended questions with scaled response options

\footnotetext{
${ }^{6}$ We contacted Michael Southworth via e-mail to ask for his papers on walkability. He sent us a copy of his questionnaire used in Santa Rosa to assess liveability. Because the questionnaire seemed useful to our study, we asked him to send us the data related to it so that we could compare it to our results. Unfortunately, the final data were not electronically available, so we used a preliminary version.
}

Regional Statistics, Vol. 7. No.1. 2017: 152-178; DOI: 10.15196/RS07109 
that allowed for statistically objective comparisons, but they did not enable us to look into the reasons for the answers. Therefore, the two approaches synergistically complemented each other and they are correctly interpreted together. Below are the results of the experts' interviews conducted with two groups: city stakeholders and city policymakers. During the experts' interviews, we obtained useful information that coloured and complemented the results of the questionnaire as expected.

1. Interviews with stakeholders: As stated above, we compared the results of interviews with four stakeholders in both cities who were relatively more involved with walkability than their cities' average citizens. We conducted the interviews individually and the average length of an interview was 25 minutes.

The first question was whether they had ever heard of walkability. Without exception, the interviewees answered 'no', so it is clear that 'walkability' is a term that had not reached the residents of these cities. The second question was about access to some important places on foot. All of the interviewees in both cities stated that they could easily walk to the majority of important places, such as schools, work, churches, banks, post offices, restaurants, and public transit stations. A Valencia respondent stated 'In Valencia, everything is within walking distance and you can go from one place to another on foot'. A respondent from Szeged stated that she could not get to the hospital/medical centre on foot and this problem surfaced in the questionnaire data as well. The third question was about the conditions of the walkways. More or less, the respondents of the two cities answered the same way, stating that more attention is paid to central areas regarding quality and cleanliness. A colleague from the county centre of Magyar Közút Nonprofit Zrt. stated 'The condition of walking paths is different depending on the neighbourhood. The problem is located in areas that have not been improved yet or the improvement was not qualitatively successful'. In Valencia, the cleanliness of the sidewalks is reportedly problematic, particularly during the summer season.

We were curious about the amenities that attracted people to walking, such as benches, public lighting, public toilets, trees, and green space. In response to our inquiry, an issue that Szeged and Valencia had in common was lack of public toilets. From the perspective of the positive features of the cities, every Valencia interviewee emphasized the Río Turia, a river that previously ran across the city, but had been transformed after a big flood into a park. One interviewee claimed 'I do believe that Río Turia is highly attractive for people living here and also for tourists'.

The Szeged interview data supported the questionnaire data on the lack of trash cans in the city. Another significant item that every interviewee considered a problem was the lack or poor condition of benches (caused by homeless people). According to the Valencia interviewees, the city is well lit, but the

Regional Statistics, Vol. 7. No.1. 2017: 152-178; DOI: 10.15196/RS07109 
Szeged interviewees complained about the lack of adequate lighting in the neighbourhoods. Regarding safety, overall, the interviews revealed no problems; however, there were some complaints. For example, some Valencia interviewees were unhappy about automobile access, even to narrow streets in the city centre where no one would expect them. The Szeged interviewees tended to report feeling unsafe because of inadequate lighting in the neighbourhoods. An area for improvement might be better separation of automobiles from cyclists. Generally, the Valencia interviewees stated that there were too many pedestrians crossing the street even if not all of the crossings were unreasonable. Furthermore, one interviewee stated 'If you follow all the rules, you need to wait a lot'. In Szeged, the interviewees generally reported that the street crossings were safe and crosswalks were well-marked, which could be the result of the city's strict requirements.

Next, the interviewees were asked about disturbing objects and activities on the walkways, such as obstructions, fire hydrants, columns, and so on. The Szeged interviewees pointed out that obstructions usually were the biggest inconveniences. Regarding disability infrastructure, Szeged and Valencia differed based on the answers of the interviewees. The Szeged interviewees claimed 'More attention is paid to this issue in the city centre, but I do not consider Szeged as a city that devotes particular attention to make the city friendlier for disabled people'. From their perspective, tactile paving exists, but it is in poor condition, and one interview stated 'The majority of tactile paving is in such bad condition that even sighted people cannot see them'. The conditions in Valencia were better, according to the interviewees' statements, such as 'Valencia is a very friendly city for disabled people'. Usually, tactile pavements also are in neighbourhoods, but there is a lack of sound signals.

After discussing walkability, and when the interviewees had gained some familiarity with the subject, we asked them for their opinions about the things that make a neighbourhood walkable. In sum, the Szeged and Valencia interviewees stated that benches and parks, cleanliness, and safety, particularly through adequate lighting, were important. The Szeged interviewees also highlighted the importance of clear distinctions between pedestrian and other traffic, a good layout, and a nice environment. Although the Valencia interviewees perceived a balance between the different participants in traffic, wide sidewalks and visibility were the most important factors to them.

We also asked them about the specific improvements they would make to their cities, and it was clear that the Szeged and Valencia interviewees would make different improvements. Szeged interviewees emphasized green space. A member of a civil organisation for protecting the environment mentioned 'Green wall and the green balcony, which is a programme of the European Union, when dwellers get free plants to increase greenery in the city'. They al-

Regional Statistics, Vol. 7. No.1. 2017: 152-178; DOI: 10.15196/RS07109 
so would improve the public lighting in the neighbourhoods, increase the number of trash cans and benches, and improve the infrastructure to accommodate disabled people. In Valencia, the new government had already implemented some improvements, but based on these data, it seems that the citizens were not completely satisfied. One interviewee stated 'They decided something which could be advantageous and comfortable for the city, but, at the same time, there are many people, many businesses that are complaining about those decisions'.

The final questions were about their characteristics, such as age, medical status, the reasons that they walk, how often they walk, and how much they walk. The average age of the Szeged interviewees was 27 years old and the Valencia interviewees were 29 years old on average. All of the interviewees reported good health appropriate for walking. The main reasons that they walked were either because they enjoyed the outdoors or that they wanted to go to particular destinations. All four of the Valencia interviewees told us that they walked every day for some reason, but the same cannot be stated about the Szeged interviewees. However, despite the more frequent walking of the Valencia interviewees, they only walked an average 70 minutes per day, which was less than that of the Szeged interviewees, which was 110 minutes per day.

2. Results of the policymakers' interviews: This section compares the results of the two interviews we conducted with one member of the Szeged government and one member of the Valencia government. The purpose of these interviews was to gain a better understanding of what happens in these cities, what improvement we might expect, and which measures are needed. The interviews comprised 13 open-ended questions and lasted about 40 minutes each.

Although 'walkability' was an unknown term in Szeged, the city had dealt with it without using that term. In Valencia, our interviewee was familiar with the term and stated that Valencia had dedicated attention to the issue. The Sustainable Urban Mobility Plan (SUMP) was mentioned by both interviewees and it was clear that it was part of both cities' mobility concepts. Sustainable mobility with the related transportation modes was highlighted as usually handled together and that walkability could not be separated from that. When asked about the reasons for implementing sustainable mobility, particularly walkability, the answers were different. The Szeged interviewee stated 'There is a complex reason. Partially there is a need to deal with it, partially there is a given situation, partially there are local issues, and, probably, the most important is that we have a truly committed deputy mayor'. The Valencia interviewee stated 'First of all, the Kyoto Protocol Plan and, besides, the SUMP guide from the European Union called Planning for People'.

Regional Statistics, Vol. 7. No.1. 2017: 152-178; DOI: 10.15196/RS07109 
Both interviewees mentioned that the European Union ensures resources. Because emphasis is on social legitimacy, the citizens of Szeged and Valencia are involved in the decision-making process. 'In the new Mobility Plan, there will be different work groups, even a civil group' was stated by the Szeged interviewee. However, 'In Valencia, there is a public participation process, called Open Mobility Table, where different sectors, different collectives can meet with politician at the regular meetings'.

The timing of the concept's implementation is different between the two cities because the Szeged government was developing the SUMP concept at the time of the interview and had just started the planning period a few weeks before the interview. However, the Transport Concept of 2007 (which is a strategic basic document of the city, a concept that contains the investment fields of the given timeframe) was future-oriented, and, therefore, there would not be a paradigm shift. Instead, socialization would mean a change, and some activities would overarch periods. On the other hand, Valencia was already realizing change. It was redesigning its public transit lines to connect the various parts of the city, even the outskirts, and there were measures for the city centre near the Central Market that aimed to close, or at least limit, automobile access to the centre and to change the directions of certain streets. During major changes, everything does not always smoothly happen, which was the case for Valencia. The main problem with the citizens occurred when traffic was directed away from the neighbourhood of the Central Market. Regarding problems during the realization period, the Szeged interviewee told us that the individuals responsible for the projects were project managers who needed to know everything about the complex projects, and other problems were the deadlines for filing applications, the calls for applications were not always direct, and there were many modifications of requirements during the application period.

From a budgetary perspective, developing walkability is a complex issue and the costs cannot be strictly defined. First, it is challenging to individually manage the various sustainable modes of transportation and the costs that can be measured are not the only costs. It is claimed that, in Valencia, the direct and indirect costs must be separated. About one year ago, there was a change to Valencia's management, and it currently does not have a large budget allocation for mobility. Consequently, low technology and inexpensive measures are employed, as elaborated in the previous paragraph.

The interviewees of Szeged and Valencia strongly agreed on recommending walkability for other cities, although, concerning the advantages and disadvantages of walkability, they highlighted different factors. The Szeged interviewee mentioned health as a physical advantage of walkability. Someone who works in an office is likely to need 20-30 minutes of physical exercise during

Regional Statistics, Vol. 7. No.1. 2017: 152-178; DOI: 10.15196/RS07109 
the day, which walking could solve. The Valencia interviewee focused on the importance of the historical city centre, and stated 'The historical city centre was built centuries ago and not designed for heavy traffic; therefore, we have to redesign it to be able to maintain its beauty. People also would be able to enjoy the sightseeing attractions without cars that disturb them'. He also stated that children would be able to play in safer conditions if traffic were limited.

\section{Synergy among the three methodologies}

By comparing the results of the observations, questionnaires, interviews with stakeholders, and interviews with policymakers in Szeged and Valencia, we identified numerous similarities and differences in the participants' opinions. Without being comprehensive, this section presents some of the most outstanding items.

Table 1

Comparison of the walkability of Szeged and Valencia based on the observations

\begin{tabular}{l|l|l}
\multicolumn{1}{c|}{ Variable } & \multicolumn{1}{c}{$\begin{array}{c}\text { Questionnaire results } \\
\text { on the more walkable city }\end{array}$} & \multicolumn{1}{c}{ Experts' interviews } \\
\hline $\begin{array}{l}\text { Accessibility of shops and ser- } \\
\text { vices }\end{array}$ & $\begin{array}{l}\text { Insignificant difference between } \\
\text { the cities }\end{array}$ & $\begin{array}{l}\text { Insignificant difference between } \\
\text { the cities }\end{array}$ \\
\hline Accessibility of public transit & Szeged & $\begin{array}{l}\text { Insignificant difference between } \\
\text { the cities }\end{array}$ \\
\hline $\begin{array}{l}\text { Accessibility of hospital/medical } \\
\text { centres }\end{array}$ & Valencia & Valencia \\
\hline $\begin{array}{l}\text { Crosswalks/pedestrian street } \\
\text { crossing }\end{array}$ & $\begin{array}{l}\text { Insignificant difference between } \\
\text { the cities }\end{array}$ & Szeged \\
\hline $\begin{array}{l}\text { Infrastructure accommodations } \\
\text { for disabled people }\end{array}$ & $\begin{array}{l}\text { Insignificant difference between } \\
\text { the cities }\end{array}$ & Valencia \\
\hline Safety & $\begin{array}{l}\text { Insignificant difference between } \\
\text { the cities }\end{array}$ & Salencia \\
\hline Attractiveness of street & $\begin{array}{l}\text { Insignificant difference between } \\
\text { the cities }\end{array}$ & $\begin{array}{l}\text { Insignificant difference between } \\
\text { the cities }\end{array}$ \\
\hline $\begin{array}{l}\text { Cleanliness } \\
\text { Source Author }\end{array}$ & Valencia \\
\hline
\end{tabular}

The best comparisons were between the questionnaire data and the experts' interviews with stakeholders because of the similarity of the questions. In general, larger differences between the two cities were found based on the experts' interviews, probably because these interviewees could articulate their thoughts and be specific in the interviews. Overall, Szeged and Valencia needed improvements; however, considering some of the most important factors, the level of walkability apparently was better in Valencia than in Szeged. There were several ways that the two cities did not differ, but Valencia seemed to be better regarding access on foot to

Regional Statistics, Vol. 7. No.1. 2017: 152-178; DOI: 10.15196/RS07109 
hospital/medical centres, disability infrastructure, safety, and attractiveness of streets (Table 1). Thus, our study found that walkability is an urban feature whose quantification is complex and difficult, and, therefore, it cannot be investigated with a single method. At least two, and, more than two if possible, synergistically complementary methodologies are needed. We suggest that walkability researchers employ several methods when quantifying walkability because doing so would provide the most complete picture of this complex topic.

\section{Quantified walkability as the basis of tailor-made walkability development tools}

This study, using the above-described methodology, provides an opportunity to develop tailor-made actions to increase the extent of walkability based on the results of the investigation. The measures described below could be part of an innovative city development toolbox for Szeged and Valencia.

Generally, considering the complex analysis of the situation, walking conditions could be improved by exploiting opportunities for land-use planning, zoning, subdivisions, site plan reviews, and street and highway designs. We propose that, when constructing an overall town layout, the focus should be on people, not automobiles, and walking should be promoted with a few changes, such as traffic speed control, safe walkway conditions, well-marked crosswalks, enjoyable and interconnected streets, and a sense of safety. To revitalize the current substandard walkable areas of a city, collaboration between the public and private sectors is essential. There are many ways to make neighbourhoods or cities more walkable, such as limiting automobile access, mixing transportation modes, improving parking access, improving transit service, protecting pedestrians, encouraging cycling, and shaping the spaces. These changes are not necessarily expensive. Cities usually prepare plans when they want to dedicate attention to improving walkability, and these plans are termed 'walkability plans'. Considering the general aspects described above, we recommend walkability plans for both cities, based on our analysis of the situation, using tailor-made tools.

When we consider all factors together, we can offer many ideas for handling the situation, although, in our humble opinion, the best alternative would be that Szeged and Valencia stay on their current paths toward implementing Sustainable Urban Mobility Plans that highlight the importance of pedestrian traffic. We suggest that one possible solution to improve walkability could be establishing multi-modal transportation systems that strongly emphasize walkability. We support Lerner-Lam et al.'s (1992) idea that rethinking our approach to development and planning could be a key to creating walkable communities.

Thus, the first steps for both cities should be creation of multi-modal transportation systems in light of the requirements of the Sustainable Urban Mobility Plans

Regional Statistics, Vol. 7. No.1. 2017: 152-178; DOI: 10.15196/RS07109 
(Figure 10). Regarding walkability, we would personally advise Szeged's and Valencia's policymakers to have regular interaction with citizens. Regarding multi-modal transportation systems, we would recommend that Szeged and Valencia develop Walkability Plans. These Walkability Plans could include specific objectives aimed at overcoming their respective walkability shortcomings. Based on our empirical research and the investigation of general solutions to increase the extent of walkability, we created a list each for Szeged and Valencia detailing possible actions that they could take. Some of these actions are similar or the same for the two cities, but some of them are targeted to one or the other city. The most important aspect of these measures is their simplicity and cost-efficiency because they mostly concern organizational matters.

Figure 10

Possible scenarios in Szeged and in Valencia for improving the level of walkability

\section{Susutainable Urban Mobility Plan}

$\sqrt{1}$

2. Multi-Model Transport System

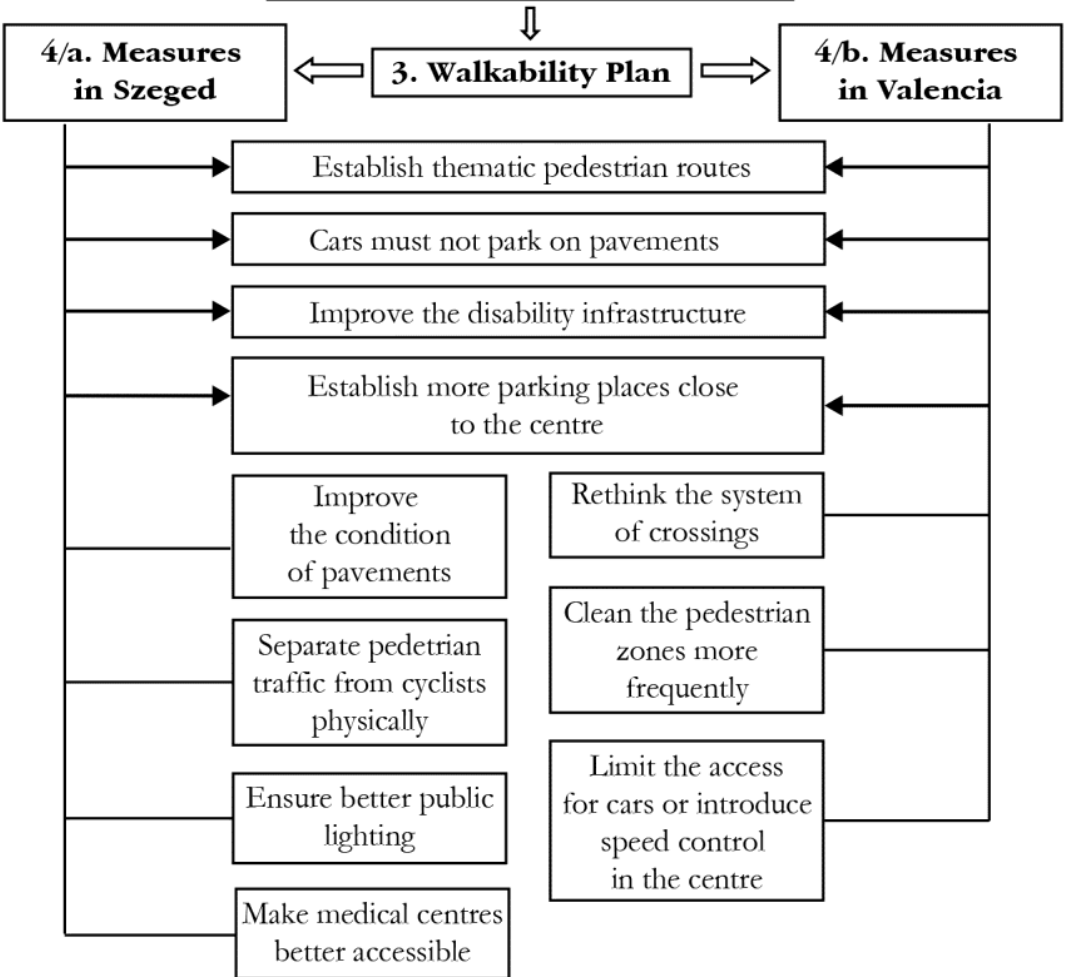

Source: Author.

Regional Statistics, Vol. 7. No.1. 2017: 152-178; DOI: 10.15196/RS07109 
We emphasize that these actions represent possible scenarios and are not the only effective solutions. However, the first four steps might be applicable to other cities eager to create a more liveable and walkable place for residents. After the fourth step, the measures are specific to Szeged or Valencia based on our empirical research findings. Similar steps could be identified for any city after a comprehensive study that reveals areas for improvement. Another significant aspect to consider is that these measures should not be implemented without thorough grounding and assessment of all their aspects and possible outcomes. Otherwise, a decision could lead to negative assessments of walkability.

\section{Summary}

This study sought to answer the question 'How is the concept of walkability understood in two mid-sized European cities, Szeged and Valencia'. To address this question, four main steps were taken, and the results are reported in this paper.

First, we studied the basic issue that this study aimed to tackle, which is the negative transportation-related effects of urbanization. Experts usually handle this situation with the help of electric transportation and public transit, and walkability is a less popular alternative solution, although it is relatively more innovative and has similar positive effects. We demonstrated the challenges to walking, the evident solutions to those challenges, the concept of 'walkability' and its benefits, and pointed out its positive effects on economies, health, and the natural environment. Second, three methods were presented to quantify walkability in communities through examples: Walk Score, Walkability Audit, and Transportation Walkability Index. Then, our empirical study was presented, for which we personally conducted fieldwork in Szeged and Valencia. The methodological structure had three levels: participant observation, survey, and personal interviews with experts (stakeholders and policymakers). These methods were essential because of the complexity and difficulty of quantifying walkability, and the three methodologies synergistically complemented each other.

In addition, Szeged and Valencia were examined in an international context for a better interpretation of the responses to two of the questions in the questionnaire. The international comparison suggested that Szeged and Valencia were relatively walkable cities. Compared to each other, some aspects favoured Szeged, and, from other aspects, Valencia seemed more walkable. However, based on the strategic dimensions of walkability, Valencia would be considered the more walkable city.

Some general solutions might help both of these cities to improve their neighbourhoods' walkability, such as land-use planning, street design, zoning, speed control, and protecting pedestrians. However, we also found that it is essential to provide specific recommendations to Szeged and Valencia, such as improving the conditions of pavements and ensuring adequate public lighting in Szeged, but cleaning

Regional Statistics, Vol. 7. No.1. 2017: 152-178; DOI: 10.15196/RS07109 
the pedestrian areas more often and rethinking the crossing system in Valencia. Both cities should focus on creating multi-modal transportation systems that strongly emphasize walkability to ensure sustainable urban mobility. This action plan also would be feasible for other cities that want to improve their local economies and transportation systems with an innovative city development toolbox.

\section{REFERENCES}

ABesamis, J.-CAMPOS, J. C.-CASTEll, C. (2013): Estimating the effects of urbanization on carbon emission: evidence in the Philippines Policy Brief 7 (1): 1-4.

Alliance FOR Biking AND Walking (2016): Bicycling and Walking in the United States: Benchmarking report http://www.bikewalkalliance.org/storage/documents/ reports/2016benchmarkingreport_web.pdf (downloaded: 23.02.2017)

Benfield, F. K. (2014): How Walkable Communities Are Good for Us http://www.huffingtonpost.com/f-kaid-benfield/how-walkablecommunities_b_6014028.html. (downloaded: 07.09.2016)

Benfield, F. K. (2016): It's a Trend: More Businesses Are Choosing Downtowns and Walkable Locations http://www.huffingtonpost.com/f-kaid-benfield/its-atrend-more-business_b_7608218.html (downloaded: 06.09.2016)

Clifton, K.-Singleton, P. A.-Muhs, C. D.-SChneider, R. J. (2015): Development of a Pedestrian Demand Estimation Tool. Transportation Research and Education Center (TREC), Portland. http://pdxscholar.library.pdx.edu/cgi/ viewcontent.cgi?article $=1331 \&$ context $=$ cengin_fac . (downloaded: 23.02 .2017 )

CoHEN, B. (2006): Urbanization in developing countries: Current trends, future projections, and key challenges for sustainability Technology in Society 28 (1-2): 63-80.

CoOper, G.-Danzinger, J. (2016): Evaluating Return: A Benefit Calculator for Active Transportation Projects ITE Journal 86 (9): 25-29.

Eidmann, J.-Long, A.-NoOmah, C.-Ury, E. (2011): A walkability study of North Adams, Massachusetts http://web.williams.edu/wp-etc/ces/North_Adams_Walkability_ Study.pdf . (downloaded: 07.09.2016)

ENYEDI, Gy. (2012): Városi világ Akadémiai Kiadó, Budapest.

EWING, R.-CERVERO, R. (2010): Travel and the Built Environment Journal of the American Planning Association 76 (3): 1-30.

Federal Highway Administration (2014): Nonmotorized Transportation Pilot Programme: Continued Progress in Developing Walking and Bicycling Networks John A. Volpe National Transportation Systems Center, Cambridge. https://www.fhwa.dot.gov/environment/bicycle_pedestrian/ntpp/2014_report /hep14035.pdf (downloaded: 23.02.2017)

FLORIDA, R. (2010): America's Most Walkable Cities http://www.theatlantic.com/business/ archive/2010/12/americas-most-walkable-cities/67988/. (downloaded: 07.09.2016)

FloridA, R. (2011): Why Walkable Cities Aren't Always the Ones You'd Think http://www.citylab.com/commute/2011/10/why-walkable-cities-arent-alwaysthe-ones-you-think/279/ (downloaded: 07.09.2016)

Regional Statistics, Vol. 7. No.1. 2017: 152-178; DOI: 10.15196/RS07109 
FlORIDA, R. (2014): Walkability is Good for You. On the internet: http://www.citylab.com/design/2014/12/growing-evidence-shows-walkabilityis-good-for-you-and-for-cities/383612/ (downloaded: 01.09.2016)

Forsyth, A.-KRIZEK, K. J.-AgRAWAL, A. W. (2010): Measuring Walking and Cycling Using the PABS (Pedestrian and Bicycling Survey) Approach: A Low-cost Survey Method for Local Communities. Mineta Transport Institute, San José. http://transweb.sjsu.edu/MTIportal/research/publications/documents/2907_r eport.pdf (downloaded: 23.02.2017)

FrANK, L.-CHAPMAN, J.-KERSHAw, S.-KAVAGE, S. (2012): City and Regional Residential Preference Survey Results for Toronto and Vencouver: A CLASP Final Report. Toronto Public Health, Toronto. https://www1.toronto.ca/city_of_toronto/toronto_public _health/healthy_public_policy/hphe/files/pdf/clasp.pdf (downloaded: 13.09.2016)

Frank L. D.-Greenwald, M. J.-Kavage, S.-Devlin, A. (2011): An Assessment of Urban Form and Pedestrian and Transit Improvements as an Integrated GHG Reduction Strategy Washington State Department of Transportation, Washington, DC. http://www.wsdot.wa.gov/research/reports/fullreports/765.1.pdf (downloaded: 12.03.2017)

GeHL, J.-Svarre, B. (2013): How to study public life IslandPress, Washington, Covelo, London.

Giles-Corti, B.-Foster, S.-Shilton, T.-FAlCOner, R. (2010): The co-benefits for health of investing in active transportation New South Wales Public Health Bulletin 21 (5-6): 122-127.

Giles-Corti, B.-Mavoa, S.-Eagleson, S.-Davern, M.-Roberts, R.-Badland, H. (2014): Transport walkability index: Melbourne McCaughey VicHealth Centre for Community Wellbeing, The University of Melbourne, Melbourne. http://www.communityindicators.net.au/files/images/How $\% 20$ walkable $\% 20$ is \%20Melbourne\%20FINAL.pdf (downloaded: 11.09.2016)

Hawkins, T. R.-Singh, B.-Majeau-Bettez, G.-Hammer Stromman, A. (2012): Comparative Environmental Life Cycle Assessment of Conventional and Electric Vehicles Journal of Industrial Ecology 17 (1): 53-64.

Institute FOR TRANSPORTATION AND DEVElopMENT POLICY (2011): Better streets, better cities: A guide to street design in urban India New York. https://www.itdp.org/wp-content/uploads/2011/12/Better-Streets-BetterCities-ITDP-2011.pdf (downloaded: 23.02.2017)

Leinberger, C. B.-Alfonzo, M. (2012): Walk this Way: The Economic Promise of Walkable Places in Metropolitan Washington, D.C. Metropolitan Policy Program at Brookings, Washington, D.C. https://www.brookings.edu/wp-content/ uploads/2016/06/25-walkable-places-leinberger.pdf (downloaded: 27.09.2016)

LeInberger, C. B.-LynCH, P. (2014): Foot Traffic Ahead: Ranking Walkable Urbanism in America's Largest Metros The George Washington University School of Business, Washington. http://www.smartgrowthamerica.org/documents/foottraffic-ahead.pdf (downloaded: 01.09.2016)

LENGYEL, I. (2010): Regionális gazdaságfejlesztés: versenyképesség, alulról szervezódés, klaszterek Akadémiai Kiadó, Budapest.

Lengyel, I.-ReChnitzer, J. (2004): Regionális gazdaságtan Dialóg Campus, Pécs.

Regional Statistics, Vol. 7. No.1. 2017: 152-178; DOI: 10.15196/RS07109 
Lerner-Lam, E.-Celniker, S. P.-Halber, G. W.-Chellman, C.-Ryan, S. (1992): NeoTraditional Neighborhood Design and Its Implications for Traffic Engineering ITE Journal 62 (1): 17-25.

Litman, T. A. (2014): Economic Value of Walkability Victoria Transport Policy Institute, Victoria. http://www.vtpi.org/walkability.pdf (downloaded: 01.09.2016)

Litman, T. (2017): Evaluating Active Transport Benefits and Costs: Guide to Valuing Walking a Cycling Improvements and Encouragement Programs. Victoria Transport Polica Institute, Victoria. http://www.vtpi.org/nmt-tdm.pdf (downloaded: 23.02.2017)

Mid-America Regional Council (1998): Creating Walkable Communities Mid-America Regional Council, Kansas City. http://safety.fhwa.dot.gov/ped_bike/docs/ marc.pdf (downloaded: 08.09.2016)

PAVLIK, G. (2015): A rendszeres fizikai aktivitás szerepet betegségek megelőzésében, az egészség megőrzésében Egészségtudomány 59 (2): 11-26.

RECHNitzer, J. (2004): A városhálózat és a régiók formálódása Magyar Tudomány 111 (9): 978-990.

RECHNITZER, J. (2007): Az európai regionális politika és városfejlődés Magyar Tudomány 168 (6): 692-704.

Smart Growth America (2015): Core Values, Why American Companies are Moving Downtown Smart Growth America, Washington. http://www.smartgrowthamerica.org /documents/core-values.pdf (downloaded: 07.09.2016)

SADORSKY, P. (2014): The effects of urbanization on $\mathrm{CO}_{2}$ emissions in emerging countries Energy Economics 41: 147-153.

SAuter, D.-PharoAh, T.-Tight, M.-MARTinson, R.-WedderburN, M. (2016): International Walking Data Standard: Treatment of Walking in Travel Surveys, Internationally standardized monitoring methods of walking and public space http://files.designer.hoststar.ch/hoststar10546/file/1-international_walking_ data_standard_version_aug_2016.pdf (downloaded: 23.02.2017)

Sieff, C.-Weissman, D. (2016): Putting Active Transportation Performance Measures into Practice ITE Journal 86 (3): 28-33.

Simmons, E.-KAY, M.-Ingles, A.-KhuranA, M.-Sulmont, M.-LyOns, W. (2015): White Paper: Evaluating the Economic Benefits of Nonmotorized Transportation. Federal Highway Administration, Washington, DC. http://www.pedbikeinfo.org /cms/downloads/NTPP_Economic_Benefits_White_Paper.pdf (downloaded: 12.03.2017)

SKM AND PWC (2011): Benefits of the inclusion of active transport in infrastructure projects. Queensland Department of Transport and Main Roads http://www.cbdbug.org.au/wp-content/uploads/north-brisbane-cycleway/13500825-file8.pdf (downloaded: 12.03.2017)

Southworth, M. (2005): Designing the Walkable City Journal of Urban Planning and Development 131 (4): 246-257.

Swartz, S. (2012): Steps to a Walkable Community: A Guide for Citizens, Planners, and Engineers. America Walks, Portland. https://www.scribd.com/document /261463434/Steps-to-a-Walkable-Community (downloaded: 12.03.2017)

Regional Statistics, Vol. 7. No.1. 2017: 152-178; DOI: 10.15196/RS07109 
TORrey, B. B. (2004): Urbanization: An Environmental Force to Be Reckoned With. http://www.prb.org/Publications/Articles/2004/UrbanizationAnEnvironmenta IForcetoBeReckonedWith.aspx (downloaded: 16.09.2016)

Transportation Research BOARD (2005): Does the Built Environment Influence Physical Activity? Examining the evidence Transportation Research Board, Institute of Medicine of the National Academies, Washington D.C. https://books.google.hu/books?id=LXWO178WopIC\&lpg=PA1\&ots=qF3Hosi WSX\&dq $=$ Does $\% 20$ the $\% 20$ built $\% 20$ environment $\% 20$ influence $\% 20$ physical $\% 2$ 0activity $\% 3 \mathrm{~F} \% 20$ Examining $\% 20$ the $\% 20$ evidence.\&lr\&hl=hu\&pg $=\mathrm{PP} 1 \mathrm{\#}_{\mathrm{v}}=$ one page\&q\&f=false (downloaded: 13.09 .2016$)$

VALE, D. S.-SARAIVA, M.-PEREIRA, M. (2016): Active accessibility: A review of operational measures of walking and cycling accessibility The Journal of Transport and Land Use 9 (1): 209-235.

VAS, Zs.-LENGYEL, I.-SZAKÁLnÉ KANÓ, I. (2015): Regionális klaszterek és agglomerációs előnyök: feldolgozóipar a magyar városrégiókban Tér és Társadalom 29 (3): 49-72.

Wang, Q.-SAntini, D. L. (1993): Magnitude and Value of Electric Vehicle Emissions Reductions for Six Driving Cycles in Four U.S. Cities with Varying Air Quality Problems Center for Transportation Research, Energy Systems Division, Argonne National Laboratory, Argonne. http://infohouse.p2ric.org/ref/ 35/34673.pdf (downloaded: 23.09.2016)

WEDDERBURN, M. (2013): Improving the cost-benefit analysis of integrated PT, walking and cycling Research Report 537, NZ Transport Agency. http://www.nzta.govt.nz/assets/resources/research/reports/537/docs/537.pdf (downloaded: 12.03.2017)

WHO (2013): Pedestrian Safety: A road safety manual for decision-makers and practitioners World Health Organization, Genf. http://apps.who.int/iris/bitstream/10665/ 79753/1/9789241505352_eng.pdf?ua=1 . (downloaded: 12.03.2017)

https://www.walkscore.com/methodology.shtml (downloaded: 17.09.2016)

Regional Statistics, Vol. 7. No.1. 2017: 152-178; DOI: 10.15196/RS07109 